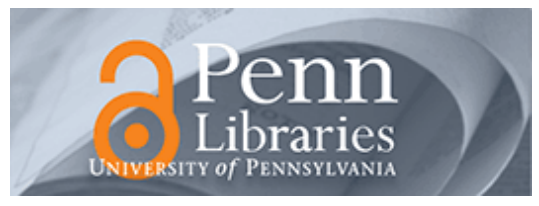

University of Pennsylvania

ScholarlyCommons

Management Papers

Wharton Faculty Research

2002

\title{
Economic Governance in an Electronically Networked Global Economy
}

Stephen J. Kobrin

University of Pennsyvania

Follow this and additional works at: https://repository.upenn.edu/mgmt_papers

Part of the Business Administration, Management, and Operations Commons, and the Economics Commons

\section{Recommended Citation}

Kobrin, S. J. (2002). Economic Governance in an Electronically Networked Global Economy. The Emergence of Private Authority in Global Governance, 43-75. http://dx.doi.org/10.1017/ CB09780511491238.004

This paper is posted at ScholarlyCommons. https://repository.upenn.edu/mgmt_papers/19

For more information, please contact repository@pobox.upenn.edu. 


\section{Economic Governance in an Electronically Networked Global Economy}

Disciplines

Business Administration, Management, and Operations | Economics 


\title{
ECONOMIC GOVERNANCE IN AN ELECTRONICALLY NETWORKED GLOBAL ECONOMY*
}

\author{
Stephen J. Kobrin
}

Department of Management, The Wharton School, University of Pennsylvania

"Geographical space as a source of explanation affects all historical realities, all spatially defined phenomena; states, societies, cultures and economies."

In the Westphalian state system the basic unit of economic governance is the national market defined, as is the sovereign state, in terms of mutually exclusive geographic jurisdiction. Economic governance -- attempts to exert authority over economies and economic actors -- is exercised through borders and territorial jurisdiction.

In this chapter I argue that the emerging global world economy compromises the effectiveness of national market-based economic governance. As the minimal spatial extent of product markets grows larger than the geographic scope of the larger national markets, the latter no longer remain viable as basic units in the world economy. As an electronically networked world economy renders economic borders less meaningful, jurisdiction loses significance. As markets are increasingly constructed in cyberspace, control through control over territory becomes problematic.

In contrast, an international or cross-border world economy comprised of a system of interconnected, geographically defined, national markets does not necessarily compromise territorial control. Although jurisdictional ambiguity or conflict may make economic governance more difficult, regulation and taxation through territorial national markets remains viable.

Globalization entails a systemic change in the organization of economics (and politics) comparable in scope to the transition from the feudal epoch the modern or Westphalian system in Europe roughly four hundred years ago. I argue that three related and interwoven characteristics of the emerging global economy are particularly problematic for authority exercised through spatially defined national markets. 
1. The scale of technology in many strategic industries (its cost, risk and complexity) renders the minimal effective market size larger than that of even the largest national markets;

2. Networks are replacing hierarchies and markets as a basic form of economic organization. The diffuse, non-centered and relational character of networks is not consistent with economic authority exercised through bounded and discrete geographic territory; and

3. The migration of markets to cyberspace (or some combination of physical and virtual space) renders geographic space problematic as a basis for effective economic governance.

As many authors have pointed out "we have been there and done that," this is actually the second global economy or second wave of globalization. ${ }^{2}$ The first global economy which dates roughly from 1870 to 1914 has been called "the high water mark" of an open, integrated international economy and the "golden age" of international economic integration. ${ }^{3}$

Pre-1914 levels of international trade and investment were striking; world trade grew by almost $50 \%$ per decade from the mid-nineteenth to early twentieth century and international capital investments by $64 \%$ per decade during the forty years before World War I. By most measures the degree of internationalization of the first global economy compares favorably with that of the current or second. To cite one relative comparison, at their late twentieth century peak Japan's capital exports (relative to GDP) were only about half of Great Britain's at the turn of the century. ${ }^{4}$

That being said, there is no question that current "global" economy differs significantly from that of a century ago. First, it is broader in terms of the number of national markets encompassed (albeit to varying degrees) as constituent units. Second, it is deeper in terms of the density of interaction, of flows of trade and investment, than it was prior to 1914.

Third, and perhaps most important, the dominant mode of organization of international economic transactions changed significantly in the late twentieth century from the market (trade and portfolio investment) to hierarchy or the internationalization of production through the MNE. ${ }^{5}$ By the late 1990s, 60,000 Transnational Corporations with over 500,000 foreign affiliates accounted for about $25 \%$ of 
global output. The United Nations Programme on Transnationals concluded that “...international production ... is at the core of the process of globalization". ${ }^{6}$

That still begs the critical question: does globalization define a change in degree or kind. Does it represent an extension of the modern international world economy into somewhat unfamiliar territory or a systemic transformation which entails both changes in quantity and quality, defining new structures and new modes of functioning? Does globalization define a fundamental change in the mode of organization of the world economy?

While there is general agreement that major changes in the scope and organization of international economic activities are taking place, considerable disagreement over their interpretation remains. ${ }^{7}$ Some argue that the interrelated economic and technological developments which are emerging as critical components of globalization will result in deep structural adjustments, leading to a major periods of change, perhaps epochal in nature. ${ }^{8}$ The French author and politician Jean-Marie Guehenno, for example, links emerging global networks with the death of nation states and the state structure. ${ }^{9}$

Others claim that all that has ended is what Eric Hobsbawm calls the "Age of Extremes," the economic dislocations and mass destruction--real or threatened--which have characterized the "short" twentieth century from 1914 to the end of the Cold War in $1991 .{ }^{10}$ One implication of this line of argument is that with the end of the "age of extremes" we are now able to return to the open, international world economy of the early twentieth century; that what appears to be dramatic change is actually a return to normalcy. Thus, Alan Blinder, who was then Vice-Chairman of the Federal Reserve observed that "...a great deal of what we have been witnessing since 1950 is simply getting the world back to the level of integration that had been achieved in 1914". ${ }^{11}$

The underlying issue, however, is not whether the level or rate of growth of trade and investment or interdependence are greater in 2000 than they were in 1900. It is whether a qualitative structural 
change is taking place and that cannot be demonstrated by quantitative arguments involving crosstemporal comparisons of economic data. ${ }^{12}$

Put differently, is the current global world economy merely "more" international or does it entail a deep change in political-economic structure? If the distinction is to have meaning, it is important to be precise about definitions. International is a relatively new word dating from the late eighteenth century, ${ }^{13}$ a modern concept which was not relevant before the emergence of territorially defined nation-states and national markets. An international economy links discrete, mutually exclusive, geographic national markets through cross-border flows of trade and investment.

"The world-wide international economy is one in which the principal entities are nation states, and involves the process of the growing interconnection between national economies...[it] is an aggregate of nationally-located functions". ${ }^{14}$ An international economy is unambiguously modern; it involves relations between sovereign units of the Westphalian state system and hierarchically structured, often vertically integrated, discrete economic actors. It is profoundly geographic in that borders of states and markets are of the essence.

The internationalization of production is not necessarily inconsistent with this framework: MNEs are seen by many observers as national firms with a clear center or home country which engage in international operations and require access to territory to function. At the end of the day, MNEs are international or cross-border entities which are of the existing interstate system and are firmly rooted in national jurisdiction.

In contrast globalization entails a qualitative transformation of the international world economy. As noted above, the argument is based on three related propositions. First, dramatic increases in the scale of technology in many industries--in its cost, risk and complexity--have rendered even the largest 
national markets too small to be meaningful economic units; they are no longer the "principal entities" of the world economy. National markets are fused transnationally rather than linked across borders.

Second, the recent explosion of transnational strategic alliances is a manifestation of a fundamental change in the mode of organization of international economic transactions from markets and/or hierarchies (i.e., trade and MNEs) to global networks. Last, and related to the second point, the emerging global economy (and many emerging global political actors) is digitally integrated and entails the migration of markets from geographic to cyberspace.

My primary interest in this chapter is the impact of globalization of the world economy on economic governance, on national markets and nation states. I argue that globalization compromises the basic symmetry of political and economic organization, of nation states and national markets, characteristic of much of the twentieth century.

An asymmetry of geographic scope is emerging as economic units (markets) expand in space well beyond the limits of political units (national territories). More important is the emerging asymmetry in mode of organization as interstate politics remains geographically grounded in the sovereign territorially while major sectors of the world economy (and many significant non-state actors) are organized in terms of non-territorial electronic networks. Geographic space is losing meaning as the basis for the organization of markets. As a result, geographically rooted economic governance has become problematic and non-state or private actors are increasingly involved in authoritative decision-making. ${ }^{15}$

The next section of this chapter deals with three components of globalization in some considerable detail: the scale of technology; alliances and cross-border networks; and the movement of markets to cyberspace. I then turn to networks and a mode of economic organization and the emergence of a networked global economy. Implications for states and the state system will then be discussed. The chapter concludes with some thoughts about possible futures. 


\section{COMPONENTS OF ECONOMIC GLOBALIZATION}

\section{Scale of Technology}

Markets, as well as economic governance, are typically conceptualized in spatial or geographic terms. In his Principles, Marshall quotes Cournot to define a market as "not any particular market place in which things are bought and sold, but the whole of any region in which buyers and sellers are in such free intercourse with one another that the prices of the same goods tend to equality easily and quickly" (emphasis added). ${ }^{16}$

That raises a pertinent but little considered question: Why should markets spread geographically beyond a local area or region? The simplest explanation, and the oldest, is that the supply of some goods is found in one locale and their demand in another: e.g., precious metals, spices and petroleum. The geographic expansion of markets also allows for a more productive division of labor: "Smithian" gains from specialization, exploitation of differences in resource endowments, and the adaptation of skills. ${ }^{17}$

Last, spreading fixed capital costs over a larger market area can reduce unit costs and produce gains from scale. The application of science and technology to production processes and products towards the end of the $19^{\text {th }}$ century provided an irresistible motive for the geographic expansion of markets. Firms found that the need for larger production runs to achieve economies of scale and, later, the demands of competitive research and development budgets, mandated expansion of the geographic bounds of markets.

In most transnationally integrated industries internationalization is driven by scale rather than specialization; a process Kenichi Ohmae characterizes as a dramatic shift from a variable to a fixed cost environment has occurred. ${ }^{18}$ He notes that in a number of critical industries, the scale of production and/or technology have increased to the point where fixed costs must be amortized over a larger market base than is available in even the largest national markets. 
While "Smithian" expansion is consistent with an international world economy, expansion driven by scale, and especially technological scale, may not be. An international world economy is constructed through the mutual interconnection or cross-border integration of national economic spaces. As Manuel Castells notes, a global economy is something different, "it is an economy with the capacity to work as a unit in real time on a planetary basis." ${ }^{19}$ An international economy links distinct national markets; a global economy fuses national markets into a coherent whole.

Furthermore, at this point it is the cost and risk of technology rather than the need for larger production runs that is the primary motivation for the transnational integration of markets. In many strategic industries international expansion is required to fully amortize the enormous research and development expenses associated with rapidly evolving process and product technology. There are only a few industries (e.g., automobiles and construction equipment) in which the fixed costs of manufacture are the motivation for international market integration, and even there developments such as computer aided design/manufacture and flexible production are reducing rapidly the number of units needed to fully exploit scale economies.

While the point is difficult to "prove," F.M. Scherer has concluded that in only a very small minority of industries is concentration approaching oligopoly at the national level justified by production scale economies in the U.S. market. ${ }^{20}$ In a previous study, Kobrin found that technological intensity was the primary determinant of the transnational integration of U.S. firms and that proxies for manufacturing scale were not significant. ${ }^{21}$

On the other hand, there is no question that the cost, risk, and pace of technological development have increased significantly over the past four decades. For example, constant dollar research and development expenditures for U.S. industry increased almost five and one-half fold between 1953 and 1990; they increased 150 percent between 1980 and 1990 alone. ${ }^{22}$ In fact, with the exception of the early 
1970s and the early 1990s, non-Federal constant dollar R\&D expenditures have grown at an annual rate of well over six percent over the last four decades. ${ }^{23}$ Research and development spending as a percentage of sales for U.S. industry doubled in the sixteen years between 1976 and 1992: from 1.9 to 3.8 percent. $^{24}$ As the extent of a company's research and development effort is mandated by the nature of its technology and competition rather than its size, this rapid growth of spending requires a corresponding expansion of sales--and ultimately, internationalization--if profitability is to be maintained. ${ }^{25}$ Put another way, it is impossible to maintain a competitive level of R\&D expenditure in industries such as pharmaceuticals, semiconductors, telecommunications, or aerospace based upon sales in even the largest national market. Firms must sell very similar products in a number of the larger markets to remain players in the industry. In that sense, the marked increase in the cost, risk and complexity of technology over the last decades of the twentieth century has fused markets globally rather than linked them internationally, at least in these strategic, technology intensive, industries.

At this point it appears that the global integration of markets by a single firm may no longer be sufficient to offset the huge costs and risks of technological development in a number of strategic industries. The last decade has seen an exponential increase in technology driven collaborative agreements or strategic alliances among leading multinationals from the major industrial countries.

\section{$\underline{\text { Strategic Alliances }}$}

Strategic alliances are relevant for two reasons. First, in many instances they are an indicator that the scale of technology--the cost, risk and complexity of research and development--has grown to the point where it is beyond the reach of even the largest and most global firms. Second, alliances are a 
manifestation of the emergence of a networked global economy; they represent a change in the mode of organization of international economic transactions.

Although comprehensive data on alliances do not exist, virtually every attempt at data gathering reveals their dramatic growth over the last two decades; one study estimated a $31 \%$ compound annual growth rate for the number of high technology alliances over the $1980 \mathrm{~s} .{ }^{26}$ Booz Allen $\&$ Hamilton reports that alliance-generated sales among the Fortune 1000 grew from less than $2 \%$ in 1980, to $19 \%$ by 1996 and they are projected to be $35 \%$ by $2002 .^{27}$

The vast majority of alliances are triad based; most studies find that over $90 \%$ of all agreements are between firms from North America, Europe and Japan. ${ }^{28}$ Alliances also tend to be concentrated in a limited number of industries: typically automobiles and high technology sectors such as pharmaceuticals, biotechnology, aerospace, information technology, and new materials. ${ }^{29}$ A single firm in these industries often enters into very large numbers of alliances: in the last half of the 1990s, IBM formed about 800 alliances, AT\&T 400 and Hewlett Packard 300. ${ }^{30}$

The motivations for strategic alliances are complex and varied. ${ }^{31}$ One is clearly global market access: the need to compete in all major markets, or at least in all the legs of the triad, simultaneously. A second reflects the continued importance of national boundaries: government preferences for "local" firms in industries such as aerospace where an alliance with a national or regional firm may be a necessary requisite of sales to either the military or a national airline. Third, one can never dismiss an interest in making competition less onerous as a motive for collaboration. ${ }^{32}$

The most important motivation for alliance formation, however, is the increasing cost, risk and complexity of technology. ${ }^{33}$ Even the world's largest and most international firms can no longer "bet the company" on the next generation of semiconductors or jumbo jets; in many industries the cost of a competitive R\&D budget has risen to the point where it is no longer possible to "go it alone." An 
example is provided by the alliance between IBM, Siemens and Toshiba to develop a 256 megabyte chip motivated by the need to share an estimated $\$ 1$ billion in development costs and the large associated risks. $^{34}$

Perhaps more important, technologies have become so complex and rapidly changing that even industry leaders cannot master them internally. An analysis of over four thousand strategic alliances where innovation or an exchange of technology represented at least part of the agreement concluded that “...cooperation has to be understood in the light of attempts made by companies to cope with the complexity and the interrelatedness of different fields of technology and their efforts to gain time and reduce uncertainty in joint undertakings during a period of technological uncertainty. Other motives appear to play a very limited role". 35

In summary, the evidence strongly suggests that the minimum size of markets needed to support technological development in industries such as aerospace, semiconductors and pharmaceuticals is now larger than the largest national markets. Furthermore, in some industries single firm internationalization no longer appears sufficient as even the largest multinationals must cooperate to deal with the cost, risk and complexity of technology. ${ }^{36}$ Alliances represent a transformation of the mode of organization of international economic transactions from hierarchically structured MNEs to networks. This has important implications for the viability of territorially defined national markets and geographically ordered economic governance which will be discussed in detail below. 


\section{Digitalization of the world economy}

The world economy is increasingly electronically integrated and digital. Networks, and especially transnational networks, are creatures of the information age held together by information technology. ${ }^{37}$ Computers, facsimile machines, high-resolution monitors, and the Internet are the "threads" of the global web of the emerging electronically networked world economy. ${ }^{38}$

More important, markets are migrating from geographic space to cyberspace as electronic commerce grows in both the business to business and business to consumer spheres. Last, and related to the first two, physical products are becoming digital services, data transmitted electronically over the Internet. (The increasing importantance of downloaded software or music in the MP3 format, provide examples.) We are entering an era where information in the form of electronic cash will be routinely exchanged for information in the form of a digital book, symphony, photograph or computer program. In short, we face a dual revolution: the migration of markets from geographic space to cyberspace and the morphing of products from real "atoms" to digital "bits." Both render geographically defined national markets and economic governance rooted in territorial jurisdiction problematic.

Thomas Malone and John Rockart argue that the electronics and information revolution has resulted in a turn about, making extra-firm coordination cheaper and more efficient once again. ${ }^{39}$ Electronic information technology facilitates the integration of geographically dispersed operations and allows networked coordination to replace ownership and hierarchy as a primary mode of control. ${ }^{40}$ One result is the emergence of flexible networks replacing production by a single large firm. Hierarchical, vertically integrated transnational firms have "fragmented" into "diverse" networks reintegrated through information technology. ${ }^{41}$

There is widespread agreement that electronic information systems are critical to alliances. Albert Bressand, Catherine Distler and Kalypso Nicolaidis, for example, argue that electronic networks 
play a central role in wealth creation as production and transactions merge into complex, information intensive processes; networks are a manifestation of the blurring of the boundary between the factory and the marketplace. ${ }^{42}$ Clarence Brown makes a similar point: as intra-firm integration increasingly depends on electronic information technologies, modern manufacturing enterprises are coming to have a great deal in common with information service firms. ${ }^{43} \mathrm{He}$ notes that this applies to inter-firm links--to subcontractors and customers--and that these linkages are rapidly becoming global in scope.

It is directly relevant that in 1995 Fortune combined the Industrial and Service "500," arguing that the new economy has virtually obliterated the distinction between industrial and service business. They note the digital revolution has "dematerialized" manufacturing, citing one source claiming that threefourths of the value added in manufacturing is now information. ${ }^{44}$ All firms, regardless of sector, are becoming information processors.

I have discussed the implications for national markets of the migration of markets to cyberspace and the digitalization of products in detail elsewhere. ${ }^{45}$ One example will make the point here.

The Indian software industry is a dramatic example of a relatively poor country entering the global economy, or to be more specific a segment of that country. The industry has grown at an annual rate of 50-69\% through the 1990s. It is also export oriented with exports in 1998-99 totaling $\$ 2.65$ billion and estimated at $\$ 3.9$ billion in 1999-00. ${ }^{46}$

Between 40 and $50 \%$ of software is exported directly over satellite or the Net. The vast majority takes the form of services, upgrading systems, installing new programs and the like. Target markets are often financial services and insurance companies in the U.S. and Europe. It is quite possible for an Indian programmer in Banaglore to be working directly on a computer in a bank in New York City, installing a new program or upgrading the system. 
That raises a question of interest: where did the transaction take place? It is far from clear which "jurisdiction" gets to tax it, or whether it is an export or an import. There is a very real possibility that national markets and territorial jurisdiction are not directly relevant when markets are constructed in cyberspace. Geography and territorial jurisdiction do not map on cyberspace.

\section{A NETWORKED WORLD ECONOMY}

Increasingly, network metaphors are used to describe the emerging world economy: a shift from standardized mass production to flexible production, from vertically integrated, large scale organizations to disaggregation of the value chain and horizontally networked economic units. ${ }^{47}$ In Dunning's terms, hierarchical enterprises are being replaced by alliance capitalism. ${ }^{48}$

The information revolution is a critical factor in the emergence of networks as a mode of organization of the world economy. Global networks are both real and virtual, in fact, many combine elements of both. Thus, Castells argues that international networks of firms and subunits of firms are the basic organizational form of the "informational/global" economy. That the "actual operating unit becomes the business project, enacted by a network". ${ }^{49}$

Similarly, UNCTAD reports that traditional oligopolies (industries with very concentrated market structures) are being replaced by global knowledge-based network oligopolies. ${ }^{50}$ These knowledge-based oligopolies share four interesting characteristics ${ }^{51}$ : collaboration aims at generating new knowledge or using or controlling its evolution; they are dynamic as collaboration focuses on shaping future boundaries of an industry or technological trajectories; they are composed of networks of firms as alliances form the basic building block of the global oligopoly; and they form across as well as within industries. (Data processing networks which involve the merger of information and communications technology are given as an example.) 
Ford, General Motors and Chrysler have announced and agreement to move virtually all of their purchasing activity to the Internet. Covisint is an on-line business to business electronic commerce network which will handle $\$ 80$ billion in annual purchasing with more than 30,000 suppliers and eventually, a $\$ 300$ billion extended supply chain. As with other business to business networks, users will be able to create marketplaces, take part in auctions and compete purchases "with the click of a mouse. ${ }^{, 52}$ By mid-2001, Covisint had grown to manage transactions which amounted to $13 \%$ of the "Big Three's" annual procurement. ${ }^{53}$

While global networks such as Covisint are revolutionary, they are but hybrid interim steps towards true informational networks. As products are digitalized -- for example software, electronic books and music-- global networks will involve exchanges of information for information, services for various versions of electronic cash that take place entirely in cyberspace. ${ }^{54}$

The emergence of networks as a basic mode of organization of international economic transactions may be of more profound importance than increases in the scale of technology. It is important to conceive of a networked world economy in terms of a complex web of transactions rather than a series of dyadic or triadic cooperative arrangements between firms. A large multinational firm may well be involved in tens if not hundreds of alliances linking various parts of its organization with others. Dicken characterizes these webs as multilateral rather than bilateral and polygamous rather than monogamous. ${ }^{55}$ I now turn to a brief theoretical discussion of networks before discussion the impact of a networked global economy on economic and political organization.

\section{Network forms of Organization}

Strategic alliances and electronic networks represent a networked mode of organization of international economic transactions which can distinguished from both trade (markets) and multinational firms (hierarchies). Although there is general agreement that networks are a basic form of economic 
organization, a central question, which is pertinent here, is whether " markets, hierarchies and networks are discrete organizational alternatives employing distinctive control mechanisms or plural forms on a continuum employing, price, authority and trust simultaneously". ${ }^{56}$

Oliver Williamson includes hybrids or networks--"various forms of long-term contracting, reciprocal trading, regulation, franchising and the like"--with markets and hierarchies as generic forms of economic organization. ${ }^{57}$ He locates hybrids on a continuum between markets and hierarchies, the polar modes of economic organization. Similarly, Wayne Baker argues that most real organizational forms fall between market and hierarchy and suggests that they are an intermediate or hybrid form of interface. ${ }^{58}$

In a very influential article, however, Walter Powell argues against portraying economic exchange as a continuum with markets and hierarchies at the poles and hybrids in between. Network forms of organization--typified by reciprocal patterns of communication and exchange--represent a distinctive mode of coordinating economic activity and economic organization. ${ }^{59}$

Similarly, an OECD report concludes that networks are a distinctive form of economic organization and the "notion of the continuum fails to capture the complex realities of know-how trading and knowledge exchange in innovation. Networks...represent a type of arrangement with its own specific distinctive features which henceforth must be considered in its own right". ${ }^{60}$

Networks have been described as "social units with relatively stable patterns of relationships over time". ${ }^{61}$ Networks differ from markets in the assumption of longer term, sequential transactions and from hierarchies in the absence of an authoritative control relationship. Networks are a social form of exchange, “...more dependent on relationships, mutual interests and reputation...network forms of exchange...entail indefinite, sequential transactions within the context of a general pattern of interaction",62 
Networks have a number of characteristics that affect the nature of international integration and interdependence. First, they are a form of "collective action" involving cooperative relationships in which the actors implicitly agree to forego the right to pursue their own interests at the expense of others. ${ }^{63}$ Network linkages entail relationships over time rather than individual or "spot" transactions; given longer term reciprocity, trust becomes critical. Network relationships are inherently or "implicitly" interdependent. $^{64}$

Second, networks do violence to the idea of formal boundaries; vertical, horizontal and spatial. ${ }^{65}$ It becomes difficult if not impossible to define organizational boundaries, to establish where one firm stops and another begins. At best, borders are blurred and ambiguous; more realistically they become conceptually irrelevant. ${ }^{66}$

Last, networks are relational, individual attributes are less important than position in determining organizational power and outcomes. "From a network perspective, variations in the actions of actors (and the success or failure of these actions) can be better explained by knowing the positions of actors relative to others...than by knowing how their attributes differ from one another." ${ }^{67}$ Thus power is a function of position in the network; as a corollary, networks have no center.

If networks are significantly different from both markets and hierarchies, trade, multinational firms and alliances (both virtual and real) represent distinct modes of organization of international economic transactions. Trade involves production by national firms in national markets linked by "arms length" spot exchanges, typically of raw materials, commodities and finished goods. MNEs internalize production: the firm's administrative hierarchy becomes the primary mode of organization of the international economy. In the integrated international firm, the exchange of intermediate goods through intra-industry and intra-firm trade becomes increasingly important. 
The emergence of global networks signals the replacement of integrated transnational hierarchies by a cooperative and reciprocal organization of economic transactions. The basic unit and venue of production become ambiguous; indeed there is a real question about the appropriateness of these terms. The most important flows across transnational networks are intangible: knowledge and information.

Although the periods overlap and are approximate, trade was the primary mode of integration of the international economy from the late nineteenth century through the first two post-World War II decades, the internationalization of production through MNEs from the mid 1960s until the mid 1980s, and alliances or networked integration emerged in the late 1980s. Two caveats are important. First, I am not proposing a "stage theory" of international integration, but rather am concerned with changes in the dominant mode over time. Second, reality is complex and messy and there are large sectors of every economy where production has remained entirely national and "networks" are confined to television and job seekers.

\section{GLOBALIZATION, NATIONAL MARKETS AND NATION STATES}

I have argued that a global economy differs in kind from the international economy which preceded it in three critical and inter-related respects. First, in many industries the scale of technology has driven the minimal size of markets well beyond that encompassed by even the largest national markets. Second, in many of these same industries electronically integrated networks are replacing hierarchies as the most important mode of organization of international economic transactions. Last, given the digitalization of the world economy and the emergence of the Internet, markets are migrating from geographic space to cyberspace. All of these trends have significant impacts on the Westphalian, territorial, organization of economics and politics.

In the nineteenth century, all production took place in discrete national markets which were linked through cross-border trade and portfolio investment. Although levels of interdependence were high and 
policy autonomy constrained, the national market was the basic unit in the international system. As noted above, the very use of the term international implies the existence of discrete and meaningful territorially defined national economic (and political) units.

In contrast, at the dawn of the twenty-first century national markets are losing meaning as the discrete units of the world economy as the scale of technology is fusing them into a larger whole. The transition to electronic networks and to cyberspace also affects the structure of the world economy. Networks are inherently interdependent, do violence to all sorts of boundaries and are constructed relationally so that the concept of a center may lose meaning.

As Castells so aptly notes, positions in the international division of labor no longer coincide with countries, "they are organized in networks and flows, using the technological infrastructure of the informational economy." ${ }^{68}$ In a similar vein, Hirst and Thompson depict national economies being subsumed and rearticulated into the global system, and argue that the international economy is becoming autonimized. ${ }^{69}$

National borders are not irrelevant. Nation states have differing interests and objectives and attempt to enforce their will on firms and other governments; national boundaries still "create significant differentials on the global economic surface". ${ }^{70}$ The critical point, however, is that globalization implies that the national economy is no longer the unit of economic accounting or the frame of reference for economic strategies. $^{71}$

Globalization may well represent a return to an earlier stage in the evolution of the capitalist world economy. Hobsbawm argues that in contrast to the past three hundred years when production was local and the world economy was based on territorially defined national economies, the current phase of development is marked by the reemergence of transnational elements. "The national economy is no longer the building block of the world economy, but has a rival in the immediately global market 
which can be supplied directly by firms capable of organizing their production and distribution in principle without reference to state boundaries..."

\section{Authority, Sovereignty, and the Geographic Order}

Robert Keohane observes that sovereignty is typically discussed rather than defined. ${ }^{73}$ Formal sovereignty is a legal concept implying supremacy within a territory and independence of outside authorities in the exercise of state authority. In contrast, autonomy and effectiveness are political constructs; the former implies that a state can and does make its own decisions with regard to internal and external issues and the latter is a measure of the extent to its purposes are achieved.

Internal sovereignty entails legitimization of the state vis-a-vis competing domestic claimants. It conceptualizes the state in the Weberian sense as having an effective monopoly of force over a territory and population, the "...undisputed right to determine the framework of rules, regulations and policies within a given territory and to govern accordingly". ${ }^{74}$

External sovereignty involves the basic principles on which the modern interstate order is based. The division of the political order into fixed, territitorially defined and mutually exclusive enclaves and mutual recognition that each state represents a specific society within an exclusive domain. ${ }^{75}$ In fact, Hendrik Spruyt argues that a primary explanation for the spread of sovereign territorial institutions was that respective jurisdictions, and thus limits to authority, could be specified precisely through agreement on fixed borders. ${ }^{76}$ In the Westphalian system, states are assumed to be the only legitimate sources of political authority.

In examining the impact of globalization on markets, states and the state system one must separate analytically constraints imposed on autonomy, effectiveness or capacity from impacts on formal sovereignty. Two sets of questions need to be asked. First, are the constraints that globalization imposes on state autonomy qualitatively different from those resulting from the interdependence associated with 
an international or cross-border world economy? If so, at what point do constraints on state autonomy compromise formal internal sovereignty? Second, will the emergence of an electronically networked global economy compromise external sovereignty: the idea of territoriality itself as a mode of economic and political organization? I believe the second question to be, by far, the most important.

\section{$\underline{\text { Globalization and Autonomy }}$}

State autonomy has never been absolute and decision making power has always been constrained by international economic transactions; the trade-off between the efficiency gains from cross-border economic activity and autonomy is far from new. The problem facing governments has always been "how to benefit from international exchange while maintaining as much autonomy as possible". 77

What is new this time around? Even if one grants that flows of trade and investment are greater in both absolute and relative terms in 2000 than in 1900 and there is "more" interdependence (however measured), that is still only a quantitative difference. Why should globalization have a qualitatively different impact on state autonomy? Does globalization -- taken in terms of the phenomena discussed in this paper -- render a state's ability to exert auhtority over its economy and over economic actors more problematic?

Participation in an international economy has always presented states with a trade-off between efficiency and a loss of autonomy, and in many instances governments have chosen to preserve the latter. Without judging their economic merit, in opting for import substitution policies such as forcing local production of automobiles, policy makers were willing to trade-off higher local costs for automobiles (reduced efficiency) for the promise of a more developed industrial capability and increased future autonomy.

That option is not available in industries such as telecommunications, pharmaceuticals, semiconductors, and aerospace where even the largest national markets are too small to support the 
research and development efforts needed to remain competitive. If transnational markets are an absolute requisite of continued technological innovation, governments face a discrete zero-one decision rather than a continuous, marginal trade-off. Accepting higher costs (e.g., lower efficiency) for some degree of autonomy is not a realistic possibility; mutual dependence is inevitable and breaking its bonds implies a degree of withdrawal that few states could tolerate. The choice is to compete transnationally or forego the next generation of microprocessors, pharmaceuticals or telecommunications technology entirely.

At a minimum, states must allow their firms to participate in global markets. While in theory governments could participate in the global economy while closing their borders to participation by others, that option is not be viable in practice. At least in these strategic industries, independence or autonomy is a very limited option. State or public authority is compromised.

At this point in many high technology industries, participating in the global economy implies participating through alliances and cooperative efforts. As Zacher notes, "[states] are becoming increasingly enmeshed in a network of interdependencies and regulatory and/or collaborative arrangements from which exit is generally not a feasible option". ${ }^{78}$

Alliances and other forms of global networks also constrain states' ability to control economic actors through territorial jurisdiction. At this point, the vast majority of MNCs are responsive to their headquarters government; even the most international have a clear center in terms of operations and management. That is not the case for alliances and the emerging knowledge-based networked oligopolies discussed earlier. They are diffuse and often relational: it is far from clear, for example, whether the American, German or Japanese government could exert substantial regulatory control over the IBMSiemens-Toshiba alliance to develop chips. Where are strategic alliances "centered"?

In an electronically networked global economy the borders of national markets, the concept of territoriality itself, and the distinction between the domestic and international economy (or domestic and 
international policy) become problematic. In Being Digital, Nicholas Negroponte makes a nice distinction between trade in atoms and trade in $\underline{\text { bits. }} .{ }^{79}$ Atoms take the form of tangible material which must cross borders physically and can be controlled by political authorities. Bits, on the other hand, are transmitted electronically, typically by satellite, which renders the borders of national markets virtually meaningless.

If software is imported in the form of disks and manuals it is subject to border controls, tariffs and the like. However, if it is transmitted digitally--downloaded from the Internet, for example--any sort of control becomes problematic and autonomy is directly constrained. As noted above, the Indian software industry has evolved from sending Indian programmers abroad to work at a client's site (known as "body-shopping") to satellite linkages through which programmers physically situated in India work directly on the client's host computer, wherever in the world it is located. ${ }^{80}$ If an Indian programmer located in New Delhi edits a program on a computer in New York there is no question that economic value has been created. It is far from clear, however, whether the transaction took place in India or the U.S. and thus, which jurisdiction gets to tax it or control it. Furthermore, neither government may actuall know that this sort of transaction took place.

In her last book, Susan Strange argued that states are losing authority, in part to markets and MNEs, and in part to other actors in the international system. ${ }^{81}$ That the authority of governments of all states has weakened as result of technical and financial change and of integration of national economies into one single global market economy. As noted in the introduction to this volume, as states' authority has weakened, a growing number of other actors have taken on authoritative roles in the international political system. These sources of "private authority include amorphous "actors" such as global financial markets and specific actors such as MNEs, both individually and collectively. They also include the rising number of NGOs and other civil society groups active in international politics. 
The question remains, however, at what point do constraints on state autonomy affect formal sovereignty? As Geoffrey Goodwin puts it, “...whether the capacity of states to order their own internal affairs and to conduct their own external policies has been so undermined or eroded as to make the concept of state sovereignty increasingly irrelevant in practice despite its persistence in legal and diplomatic convention." 82 Although this question is not immediately answerable, it is none the less, critically important.

\section{External sovereignty and territoriality}

All forms of political organization occupy geographic space. However, that does not mean that they are territorial, systems of rule "predicated on and defined by fixed territorial parameters" ${ }^{83}$ The distinguishing characteristic of the modern state is that it is territorial, and that of the modern state system that it organizes geographic space. As James Anderson notes:

"Modern states...are all territorial in that they explicitly claim, and are based on, particular geographic territories, as distinct from merely occupying geographic space which is true of all social organizations...territory is typically continuous and totally enclosed by a clearly demarcated and defended boundary...",84

What makes the modern state system historically unique is this "differentiation" into "territorially defined, fixed and mutually exclusive enclaves of legitimate dominion". ${ }^{85}$ Joseph Camilleri and Jim Falk argue that the first function of the sovereign state was the organization of space and that the spatial qualities of the state "is integral to the notion of sovereignty and international relations theory." ${ }^{\text {" }}$ As Ronald Deibert notes, what might be called "High Westphalia -- a condition of territorial exclusivity and spatial differentiation" is what marks the modern period. ${ }^{87}$

The modern construction of economics is also inherently territorial; the market, national markets, and even the international economy are geographic constructs. As noted above, national markets were created by political authorities to territorialize economic activity. ${ }^{88}$ 
In general, regional markets--the European Union is the best example--are motivated by the need to expand the geographic bounds of national markets to increase efficiency in terms of specialization and/or scale. An international economy, then, is comprised of national or regional economic spaces linked through economic transactions; economic integration is the extension of a market in geographic space. ${ }^{89}$ In part, globalization involves "deepening” or closer integration across national, regional and global geographic spaces. ${ }^{90}$

An argument has been made that regardless of how international the world economy becomes, at the end of the day all economic activity takes place within national boundaries. ${ }^{91}$ The implication is that even the most integrated MNE does not alter the basic geographic structure of the world economy; any given step in the production process or any given economic transaction can be located precisely in geographic space and thus assigned unambiguously to a specific national territorial jurisdiction and national market. While that argument may hold for a modern international economy, it is not necessarily valid in a post-modern, electronically networked global economy.

There is nothing in the nature of markets that demands that they be defined spatially. In part, the spatial definition of markets is a function of the stage of technological development, the need for physical contact between buyers and sellers. In part, it is a result of the path of development of the modern political-economic system. Many of the emerging global networks construct markets in electronic rather than geographic space. The international financial system provides both the best current example and a metaphor for the future.

The world financial market is not comprised of linked national markets; in fact, it is not comprised of geographic locations at all. It is a network integrated through electronic information systems; hundreds of thousands of electronic monitors in trading rooms all over the world linked together through satellites. ${ }^{92}$ It is a system which is no longer nationally centered, “...in which national markets, physically 
separate, function as if they were all in the same place." Global financial integration has been described as "the end of geography". 93

If a trader in New York presses a key on her computer and buys German Marks in London, where did the transaction take place? Chase Manhattan Corporation has built a center to process transactions worth trillions of dollars each year in Bournemouth England linked by satellite to its offices in New York, Hong Kong, Luxembourg and Tokyo. Would anyone argue that all of these "transactions" can be located in the United Kingdom ${ }^{94}$

The concepts of geographic space do not apply directly to cyber space. It is far from clear what do jurisdictions and boundaries mean when markets take the form of information systems. One can question whether all economic activity takes place within national boundaries or even whether economic activity can occur in more than one place at the same time. At the end of the day, the real question is whether the spatial concepts of borders, territory and jurisdiction apply to electronically organized global networks.

The information revolution--the linking of telecommunications and computers--makes the very idea of a market as a geographic construct obsolete; they have become global networks rather than places. ${ }^{95}$ Ruggie suggests that a nonterritorial region is emerging in the world economy, “...a decentered yet integrated space-of-flows...which exists along side the spaces-of-places that we call national economies." He goes on to note that in this nonterritorial region the distinctions between internal and external become problematic. $^{96}$

In summary, the very idea of a national market as an economic (or political) construct appears to have lost meaning in the post-modern world economy. As Peter Dombrowski and Richard Mansbach observe, "Markets are now effectively deterritorialized, and there is a growing incompatibility between the political boundaries of states and the economic boundaries of markets." $" 97$ 
Given the emergence of electronic global networks, neither territoriality nor mutually exclusive geographic organization retain relevance. The result has been to strip markets of both geographic and political meaning. The net effect of both is to raise questions about the meaning of sovereignty -- at least relative to economies and economic governance -- in its external sense of a system ordered in terms of mutually exclusive territoriality.

Sovereignty and modernity cannot be separated. Both entail the unambiguous and mutually exclusive ordering of space; both are profoundly geographic. Camilleri and Falk go so far as to claim that "Sovereignty, both as an idea and an institution, lies at the heart of the modern and therefore Western experience of space and time." 98

Both Gianfranco Poggi and Friedrich Kratochwil note a crisis of territoriality. The latter observes that the fact that political systems are territorial and boundary maintaining and economic systems are not affects the very core of the state as a political entity. ${ }^{99}$ It is to that asymmetry that I now turn.

\section{ECONOMIC AND POLITICAL GEOGRAPHY}

While one can certainly agree with Miles Kahler that international economic space seldom coincides perfectly with political space, during the most of the twentieth century there was a rough symmetry between politics and economics: both nation states and national markets have been bounded by the same set of unambiguous borders and organized geographically. ${ }^{100}$ Nation states and national markets, however, are but one of a number of historical modes of organizing political and economic authority and, in historical terms, relatively short lived ones at that. ${ }^{101}$ It is not unreasonable to argue that the symmetry between states and markets in both geographic scope and mode of organization--which we tend to take as the natural order of things--is characteristic only of a very brief window of time: perhaps the hundred years spanning the late nineteenth to late twentieth centuries. 
Martin Parker makes a nice distinction between post-modern as a historical period and postmodern as a theoretical perspective (he uses the hyphen to distinguish between the two). ${ }^{102}$ Thus, one can meaningfully talk about a modern or Westphalian political-economic system structured in terms of unambiguous territorial jurisdiction or the transition from modern to post-modern organizations in terms of the disintegration of "Fordist" vertically integrated hierarchical firms, without assuming a postmodern epistemology.

At the start of the twenty-first century a post-modern global economy is situated in a political system which is still grounded, at least conceptually, in modernity. As noted above, in many of the industries now regarded as strategic, the minimal market size needed to support a competitive research and development effort is larger than even the largest national markets, they are no longer the basic structural unit of the global economy.

Perhaps of more fundamental importance, most of the concepts we use to understand international politics are still organized in terms of territory and borders. Economic activity, on the other hand, is increasingly organized in terms of electronic networks. The result is a developing asymmetry of scope and mode of organization between a modern, territorially based and geographically organized international political system comprised of nation states and an emerging post-modern world economy where national markets, and indeed, the very concepts of territoriality and geography are becoming less relevant.

That being said, two caveats are necessary. First, as will be discussed below, the international political system is also in the midst of traumatic change. As is discussed elsewhere in this volume, nonstate and non-territorial actors are emerging which wield significant "private" political authority. Second, neither the international nor the global world economy are all encompassing. Many sectors of economic activity are still domestic and little affected by cross-border transactions, many others remain grounded in 
a cross-border or international economy. While the focus of this Chapter is on post-modern as an historical period rather than postmodern as an epistemology, the simultaneous existence of domestic, international and global economies would not be inconsistent with the latter.

\section{BACK TO THE FUTURE ${ }^{103}$}

Geoffrey de Joinville, a thirteenth century French medieval lord, acquired a considerable portion of Ireland through a "strategic alliance." His half-sister's husband--the uncle of the Queen of England-arranged a marriage with Matilda, granddaughter of Walter de Lacy, Lord of Meath, who brought substantial Irish lands with her. ${ }^{104}$ After his marriage, de Joinville owed simultaneous allegiance to the Kings of England and France.

As E.H. Carr argued many years ago, it is difficult for contemporary observers to even imagine a world in which political power is organized on a basis other than territory. ${ }^{105}$ However, neither de Joinville's fiefdoms nor the international financial market are modern, geographically based forms of political or economic organization. Political control in one case and economic transactions in the other are organized without regard to mutually exclusive geography or meaningful and discrete borders. To a large extent both pre- and post-modern forms of organization are aterritorial.

Over twenty years ago Hedley Bull argued that the emergence of a modern and secular counterpart of Western Christendom, with its characteristic overlapping authority and multiple loyalties,

was within the realm of possibility. ${ }^{106}$ The post-modern future may well resemble the medieval past more closely--at least metaphorically--than the more immediate, geographically organized world of national markets and nation states.

Although medieval "states" occupied geographic space, politics was not organized in terms of unambiguous geography. Political authority took the form of hierarchical personal relationships, often overlapping and intertwined mutual obligations and rights as de Joinville well illustrates. Borders were 
diffuse, representing a projection of power rather than a limit of sovereignty. In that context, power and authority could not be based on mutually exclusive geography.

The Middle Ages lacked the singular relationship between authority and territory characteristic of the modern era; geographic location did not determine identity and loyalty. Overlapping and competing political authorities were the norm rather than the exception. At times, the spheres of pope, emperor, prince and lord were all interwoven and comprised complex aterritorial networks of rival jurisdiction.

Citing other sources, John Ruggie (1983:274) describes the medieval system of rule in terms of a "patchwork" of overlapping and incomplete rights of government which were "inextricably superimposed and tangled." He labels the medieval institutional framework heteronomous, connoting a "lattice-like network of authority relations." These overlapping, interwoven and incomplete systems of authority often resulted in competing claims to the same geographic area. ${ }^{107}$

To assert singular territorial authority, early modern monarchs had to exert primacy over a patchwork of dukedoms, principalities and other localized authorities as well as transnational institutions such as the papacy, monastic and knightly orders. Until that was accomplished, the concept of an unambiguous relationship between authority and territory was unknown.

Sovereignty--in its modern sense--is unambiguous political authority. The underlying idea of the modern political system is exclusive authority over a discrete geographic space, which entails the absence of both domestic competitors and extraterritorial superiors. It implies that the state is the ultimate domestic authority and bows to no external power, be it pope or emperor. ${ }^{108}$

Singular territorially based authority is once more becoming problematic in our emerging postmodern global political economy. States are no longer the sole sources of legitimate authority, in fact we face a world of overlapping and ambiguous "authorities" which may shift as the context changes. As noted above, MNEs and markets are one source of authority in the international system and NGOs 
and other civil society groups another. There are times when significant international political negotiations have involved these two sets of actors with states on the sidelines.

An excellent example is the battle over the price of AIDS drugs in Africa and other poor regions in late 2000 and the spring of 2001. After considerable negotiation and pressure from a variety of well organized groups, the pharmaceutical companies offered to reduce dramatically the price of "AIDS cocktails" in South Africa and a number of other African countries. What is of interest here is that the primary negotiators were the private sector - pharmaceutical multinationals - and NGOs including Doctors without Borders and a range of AIDS activists. The principal actors were private authorities rather than states. ${ }^{109}$

While the medieval analogy has very obvious limits, the past may well contain applicable lessons for the future. A neat, unambiguous ordering of economic and political authority along geographic lines may no longer be the norm. Borders are diffuse and permeable, compromised by transnational integration and global telecommunications. Relationships are increasingly networked rather than hierarchical with both individuals and organizations enmeshed in complex, polygamous world-wide webs. Multiple and competing loyalties result.

James Rosenau foresees the emergence of a dual system of sovereignty bound and sovereignty free actors--or state centric and multicentric worlds--coexisting together. "The result is a paradigm that neither circumvents nor negates the state-centric model but posits sovereignty-bound and sovereigntyfree actors as inhabitants of separate worlds that interact in such a way as to make their coexistence possible". 110

One of the primary characteristics of modernity is a lack of ambiguity. The international political system is structured in terms of discrete and mutually exclusive geography: disputed border areas aside, every point in geographic space belongs unambiguously to a single nation state and market. With very 
few exceptions every individual under the law, including corporations, is a citizen of a single state. Similarly, the essence of the modern integrated economic organization is a clear hierarchy and a single chain of command: one boss, one company. Every individual, and every transaction, can be located in organizational space.

We may well be at a point of transition comparable to what Ruggie describes as the "most important contextual change in international politics in this millennium: the shift from the medieval to the modern international system." ${ }^{111}$ The emergence of an electronically networked global economy may herald an analogous transition to a post-modern political-economic system.

There is, however, a danger in trying to project modern assumptions into a post-modern era. Linearity or unrepeatable time is basic to modernity. ${ }^{112} \mathrm{We}$ assume that time's arrow is unidirectional and that progress is irreversible; that there is an historic progression from classical to medieval to modern to-perhaps--post-modern. That assumption may be wrong.

\section{THE STATE?}

This chapter has argued that globalization will markedly constrain the autonomy and effectiveness of states and, at a minimum, raise serious questions about the meaning of internal and external sovereignty. One point should be clear: I am not claiming that the state will wither away or even be rendered impotent. Rather, that globalization will affect the structure and functioning of both states and the inter-state system.

At a minimum states will be still be responsible for any number of critical functions: for the welfare of their citizens, for basic social and physical infrastructure and for insuring economic viability, albeit in a very different context. Furthermore, while globalization will transform relatively large number of critical, strategic sectors, it certainly does not affect all sectors, firms and individuals equally. There 
will still be firms that function as domestic actors and those that function in a more traditional international or cross-border economy.

There is no question, however, that the meaning of sovereignty will evolve and that the state's role relative to supra- and sub-national actors will change. The medieval analogy is useful. It should be clear at this point that I agree with Hirst and Thompson that the political order is becoming more polycentric with states seen as "one level" in a very complex system of often overlapping and competing agencies of governance. ${ }^{113}$ As discussed elsewhere in this volume, states are no longer the sole source of political authority, private political authorities have emerged and coexist with public authorities in an complex, interwoven and ambiguous relationship.

There is certainly some recognition of the need for some sort of control at the center. The World Trade Organization (for example) has been given greater adjudication powers than its predecessor (The GATT). Furthermore regional agreements such as the EU, NAFTA and ASEAN appear to be proliferating. While the future of the EU is far from clear at this point, that fact that a common currency is even on the table has major implications for state sovereignty.

At the same time, there appears to be increasing pressure for devolution of powers downwards to sub-national entities, whether they are individual states in federal systems such as the United States or regions within Europe. The situation is complicated further by the rise of non-governmental organizations (NGOs) as important actors in international politics; one thinks immediately of Greenpeace in environmental politics or Amnesty International in human rights.

The modern system of political and economic organization may well have been an exception. There is no reason to assume that a lack of geographic ambiguity, or even territoriality itself, is inherent in the human condition. ${ }^{114}$ The post-modern era may well resemble the medieval in terms of ambiguity, multiple loyalties, multiple levels of authority and the coexistence of multiple types of political and 
economic actors. It is certainly consistent with a post-modern world view to reject the "modernist narrative of progress" and "embrace many simultaneously different and even contradictory accounts of reality". 115

A medieval lord dealt with allegiances to multiple sovereigns, perhaps an emperor, and the coexistence of secular and sacred authority as the norm. Is there any reason a post-modern could not deal with sub-national, national, regional, international, civil society, and supra-national "authorities" simultaneously? Or with multiple and ill-defined allegiances? Or with a system ordered on some basis other than geography?

This chapter has argued that globalization entails the technologically driven expansion of the scope of markets well beyond the limits of even the largest national territories, the replacement of markets and hierarchies by relational networks as the mode of organization of international economic transactions, and the migration of markets to cyberspace. Globalization signifies the emergence of a post-modern world economy that is not consistent with a modern, territorially defined, international political system. While the emerging asymmetry could be resolved by some sort of "world order," that is not likely in the foreseeable future. Modern economic and political actors will have to learn to deal with the ambiguity and uncertainty of the post-modern future. 


\section{NOTES}

* This chapter is a revision of "The Architecture of Globalization" State Sovereignty in a Networked Global Economy" Chapter 5 in John H. Dunning, ed. Governments, Globalization and International Business, Oxford: Oxford University Press, 1997. I would like to thank Mark Casson, John Dunning, Vicki Golich, Ben Gomes-Cassares, John Ikenberry, Robert Keohane, Bruce Kogut, Robert Kudrle, Richard Lipsey, Richard Locke, Tom Malnight, Simon Reich, John Ruggie, Karl Suvant, John Stopford and Raymond Vernon for comments on previous drafts. The Reginald Jones Center at the Wharton School provided partial support for this research.

\footnotetext{
${ }^{1}$ Fernand Braudel Afterthoughts on Material Civilization and Capitalism (Baltimore: Johns Hopkins University Press, 1986), p. 20

${ }^{2}$ Richard E. Baldwin and Phillipe Martin, “Two Waves of Globalization: Superficial Similarities, Fundamental Differences,” Working paper 6904 (National Bureau of Economic Research, 1999). ${ }^{3}$ Paul R. Krugman, "A Global Economy is Not the Wave of the Future” Financial Executive (March-
} April, 1992). John Dunning, Multinational Enterprises and the Global Economy (Reading, MA: AddisonWesley, 1993). Paul Streeten, Interdependence and Integration of the World Economy: The Role of States (New York: Oxford University Press, 1992), pp. 125-126.

${ }^{4}$ Martin Wolf, “Globalization and the State” Financial Times September 18, 19995, p. 22. Sodersten and Rosencrance, et al. argue that prior to World War I, international trade was a higher proportion of national income and direct and indirect investment a larger fraction of GNP than at present (the mid 1970s). See Bo Sodersten, International Economics (New York: St. Martin's Press, 1980) and Richard Rosecrance, A. Alexandroff, W. Kochler, J. Kroll, S. Laquer, and J. Stocker "Whither Interdependence" 
International Organization 31 (1977): 385-424.

${ }^{5}$ In 1998, sales of subsidiaries of MNEs abroad (\$11 trillion) substantially exceeded exports of $\$ 7$ trillion, see United Nations Conference on Trade and Development. World Investment Report: 1999. (United Nations: New York and Geneva, 1999), p. xix. Furthermore, a significant proportion of what appears to be trade is actually cross-border intra-firm transfers, and sales of subsidiaries of MNEs located outside of the home country now substantially exceed the value of goods "traded" internationally. At this point, United Nations Conference on trade and Development estimates that intra-firm trade accounts for about $35 \%$ of all international transactions and for the U.S., sales of affiliates exceeds cross-border sales of goods and services by a factor of 2.5 to 1 , United Nations Conference on Trade and Development. "Trends in Foreign Direct Investment." (UNCTAD: Geneva, TD/B/ITNC/2, 1995). ${ }^{6}$ UNCTAD 1999, p.xvii,xix. For a dissenting view on the tendency towards the internationalization of production see David M. Gordon, “The Global Economy: New Edifice or Crumbling Foundations?” New Left Review (March-April, 1988): 24-65.

${ }^{7}$ Peter Dicken, “The Roepke Lecture in Economic Geography. Global-local Tensions: Firms and States in the Global Space-economy.” Economic Geography 70(1994): 101-102.

${ }^{8}$ Richard G. Lipsey and Cliff Bekar, A Structuralist View of Technical Change and Economic Growth. In Bell Canada Papers on Economic and Public Policy vol. 3 Proceedings of the Bell Canada Conference at Queen's University, November 1994 to be published by the John Deutch Institute. Second publisher's version March 20, 1995. See also Martin Albrow, The Global Age: State and Society Beyond Modernity. (Stanford: Stanford University Press, 1997).

${ }^{9}$ Jean-Marie Guehenno, “Asia May Offer a New Model of Politics.” International Herald Tribune (May 
16, 1994).

${ }^{10}$ Eric J. Hobsbawm, The Age of Extremes: A History of the World, 1914-1991. (New York: Pantheon Books, 1994).

${ }^{11}$ The New York Times. (March 12, 1995), p. E5

${ }^{12}$ Charles-Albert Michalet, "Transnational Corporations and the Changing International Economic System." Transnational Corporations 3 (1) (1994): 6-22.

${ }^{13}$ The Oxford English Dictionary attributes its first use to Bentham in 1780 in a discussion of international jurisprudence in which he explicitly states that the word is a new one.

${ }^{14}$ Paul Hirst and Graham Thompson, "The Problem of Globalization: International Economic Relations, National Economic Management and the Formation of Trading Blocs." Economy and Society 21 (4) (1992): 358-360.

${ }^{15}$ See Claire A. Cutler, Virginia Haufler and Tony Porter, Private Authority in International Affairs, Albany:State University of New York Press, 1999.

${ }^{16}$ Alfred Marshall, Principles of economics 8th ed. (London: MacMillian and Co, 1961), pp. 270 and 274.

${ }^{17}$ Smithian growth results from "the creation of commerce and voluntary exchange between two previously disjoint units --be they individuals, villages, regions, countries or continents." William N. Parker, Europe, America and the Wider world: Essays on the Economic History of Western Capitalism 1:1 (Cambridge: Cambridge University Press, 1984), p.1. Also see Joel Mokyr, The Lever of Riches: Technological Creativity and Economic Progress (New York: Oxford University Press, 1990), pp. 4-6.

${ }^{18}$ Kenichi Ohmae, The Borderless World (New York: Harper Business, 1990). 
${ }^{19}$ Manuel Castells, The Rose of the Network Society (Malden, MA: Blackwell Publishers, 1996), 93.

${ }^{20}$ F.M. Scherer, "Economies of Scale and Industrial Concentration." In Harvey Goldschmitt, H. Michael Mann and J. Fred Weston (eds.). Industrial Concentration: The New Learning (Boston: Little Brown and Company, 1974). Scale economies and notions such as minimally efficient plant size are notoriously difficult to measure in practice, especially across a range of

${ }^{21}$ Stephen J.Kobrin, “An Empirical Analysis of the Determinants of Global Integration,” Strategic Management Journal. (12) (1991).

${ }^{22}$ J.E. Jankowski, jr., National Patterns of R\&D Resources (NSF 92-330 Washington: National Science Foundation, 1992).

${ }^{23}$ Ibid.

${ }^{24}$ See Business Week, "R\&D Scoreboard" (June 27, 1994), pp. 78-103 and Business Week, “Technobanking Takes Off” (November 18, 1994), pp. 52-53.

${ }^{25}$ The point can be illustrated anecdotally. For example, in 1993, Merck spent $11.2 \%$ of its sales on $R \& D$ and $43.7 \%$ of its sales were outside the U.S. If it were forced to support the costs of technological development, which are exogenously determined, on its U.S. volume alone (64.3\% of the total) it would have had to spend $21 \%$ of its sales on R\&D, a proportion not tenable over any but the shortest time period. Corresponding figures for some other firms, that is R\&D spending as a proportion of U.S. sales only, are: Intel, 22\%; Pfizer, 24\%; Motorola, 17\% and Lilly, 24\%. Data obtained from Business Week, (1994) and Forbes, “The International 500" (June 18, 1994)

${ }^{26}$ See Benjamin Gomes-Casseres, "Computers: Alliances and Industry Evolution,” in David B. Yoffee (ed.). Beyond Free Trade: Firms, Governments and Global Competition (Boston: Harvard Business School Press, 1993), pp. 79-128; Lynn Krieger Mytelka, Strategic Partnerships: States, Firms and 
International Competition (Rutherford, N.J.: Fairleigh Dickinson University Press, 1991); Richard N.

Osborn and C. Christopher Baughn, "Forms of Interorganizational Governance for Multinational

Alliances," Academy of Management Journal 33 (1990), pp.503-519; and Vern Terpstra and Bernard L.

Simonin, "Strategic Alliances in the Triad: An Exploratory Study," Journal of International Marketing 1

(1993), pp. 4-25 among many others. The LARA/CEREM data base, for example, of 1,086 agreements involving at least one European partner shows an average of 67 a year in 1980-82, 133 in 1983-85 and

243 in 1986-87, Mytelka, Strategic Partnerships: States, Firms, and International Competition, pp. 10-11

${ }^{27}$ Quoted in Gabor Garai, "Leveraging the Rewards of Strategic Alliances,” Journal of

Business Strategy 20(2) (1999), pp. 40-43.

${ }^{28}$ U.S. Congress, Office of Technology Assessment, Multinationals and the National Interest: Playing by

Different Rules (OTA-ITE-569 Washington: U.S. Government Printing Office, 1993).

${ }^{29}$ U.S. Congress, Office of Technology Assessment, Multinationals and the U.S. Technology Base

(OTA-ITE-612 Washington: US. Government Printing Office, 1994).

${ }^{30}$ Garai, "Leveraging the Rewards of Strategic Alliances."

${ }^{31}$ Mytelka, Strategic Partnerships: States, Firms and International Competition.

${ }^{32}$ Raymond Vernon argues that this is the primary motivation for the current wave of strategic alliances.

Letter to the author, November 1993.

${ }^{33}$ Again, while generalization is difficult, existing data do appear to support technology as the dominant driver of inter-firm cooperative agreements. An OECD report, for example, sums evidence from "one of the best data banks" to conclude that R\&D cooperation represents the single most important objective of inter-firm agreements, OECD, Technology and the Economy: The Key Relationship, (Paris, 1992).

Similarly, in reviewing a number of empirical studies Mytelka concludes that knowledge production and 
sharing is an increasingly important component of strategic partnerships, Lynn Krieger Mytelka, Strategic Partnerships: States, Firms and International Competition, p. 9

${ }^{34}$ UNCTAD, World Investment Report: 1993.

${ }^{35}$ John Hagedoorn, “Understanding the Role of Strategic Technology Partnering: Interorganizational Modes of Cooperation and Sectoral Differences," Strategic Management Journal 14 (5) (1993), p. 378.

${ }^{36}$ A caveat is necessary. Although the growth of alliances has been dramatic over the last decade, their presence is not universal. While the data are still fragmentary, alliances appear to concentrate in industries characterized by technological or capital intensity. It should be noted, however, that these industries (e.g. aerospace, semiconductors, telecommunications and automobiles) are the most important strategically in terms of national economic competitiveness and security

${ }^{37}$ Stewart R. Clegg, Modern Organizations ( London: Sage, 1990).

${ }^{38}$ Robert B. Reich, The Work of Nations (New York: Alfred A. Knopf, 1991).

${ }^{39}$ Thomas W. Malone and John F. Rockart, “How Will Information Technology Reshape Organizations? Computers as Coordination Technology," in Stephen Bradley, Jerry A. Hausman and Richard L. Nolan (eds.), Globalization, Technology, and Competition: The Fusion of Technology and Computers in the 1990s (Boston: Harvard Business School Press, 1993), pp. 37-56.

${ }^{40}$ Dicken, "The Roepke Lecture in Economic Geography. Global-local Tensions: Firms and States in the Global Space-economy."

${ }^{41}$ Martin Parker, “Post-modern Organizations or Postmodern Theory?” Organization Studies 13 (1) (1992), p. 9.

${ }^{42}$ Albert Bressand, Catherine Distler and Kalypso Nicolaidis, "Networks at the Heart of the Service Economy," in Albert Bressand and Kalypso Nicolaidis (eds.), Strategic Trends in Services (New York: 
Ballinger, 1989), pp. 17-33.

${ }^{43}$ Clarence Brown, "New Concepts for a Changing International Economy." The Washington Quarterly 11 (1) (1988).

${ }^{44}$ Thomas A. Stewart, “A New 500 for the New Economy,” Fortune (May 15, 1995), pp.168-178.

${ }^{45}$ Stephen J. Kobrin, “You Can’t Declare Cyberspace National Territory: Economic Policy Making in the Digital Age," in Don Tapscott, Alex Lowy and David Ticoll (eds.), Blueprint to the Digital Economy (New York: McGraw-Hill, 1998b), pp.355-370.

${ }^{46}$ Financial Times, (December 1, 1999).

${ }^{47}$ UNCTAD, World Investment Report: 1993; Manuel Castells, "The Informational Economy and the New International Division of Labor," in Martin Carnoy, Manuel Castells, Stephen S. Cohen and Fernando Henrique Cardoso (eds.), The New Global Economy in the Information Age (University Park, PA: The Pennsylvania State University Press, 1993), pp. 15-43; Charles-Albert Michalet, "Strategic Partnerships and the Changing Internationalization Process," in Lynn K. Mytelka (ed.), Strategic

Partnerships and the World Economy (Rutherford, N.J.: Fairleigh Dickenson Press, 1991), pp. 35-50; and The Economist. "The Global Firm: RIP,” (February 6, 1993), p. 69.

${ }^{48}$ John H. Dunning, Globalization, Economic Restructuring and Development. The Sixth Raul Prebish Lecture. Also see David Harvey, The Condition of Postmodernity (Cambridge: Blackwell Publishers, 1990) for references to the large and growing literature on this topic.

${ }^{49}$ Castells, The Rose of the Network Society, pp. 191, 165.

${ }^{50}$ UNCTAD, World Investment Report: 1999, p.107.

${ }^{51}$ These characteristics and much of the discussion is drawn from Lynn Krieger Mytelka and Michel 
Delapierre, "Strategic Partnerships, Knowledge-based Networks and the State," in Claire Cutler, V. Haufler and T. Porter (eds.) Private Authority and International Affairs (Binghamton: SUNY University Press, 1999), pp. 129-149.

${ }^{52}$ Electronic Buyer's News (December 6, 1999) and Crain's Detroit Business (November 8, 1999).

${ }^{53}$ Steve Konici, “Covisint Books Impressive Procurement Volume.” Informationweek.com, July 18, 2001. (www.informationweek.com.)

${ }^{54}$ Stephen J. Kobrin, "Electronic Cash and the End of National Markets.” Foreign Policy (June, 199).

${ }^{55}$ Peter Dicken, “The Roepke Lecture in Economic Geography. Global-local Tensions: Firms and States in the Global Space-economy."

${ }^{56}$ Candace Jones and William S. Hesterly, “A Network Organization: Alternative Governance Form or a Glorified Market?” (Presented at the Academy of Management Meeting, Atlanta, August, 1993), p. 3. The literature on networks is large and growing. For an introduction and references see: Sumantra Goshal and Christopher A. Bartlett, "The Multinational Corporation as a Strategic Network," The Academy of Management Review 15 (1990), pp. 603-625.; Raymond Miles and Charles C. Snow. “Organizations: New Concepts for New Norms,” California Management Review XXVII (3) (1986), pp. 62-73; Nitin Nohria and Robert C. Eccles, Networks and Organizations: Structure, Form and Action (Boston: Harvard Business School Press, 1992); and Barry Wellman and S. D. Berkowitz, Social Structures: A Network Approach (Cambridge: Cambridge University Press, 1988).

${ }^{57}$ Oliver E. Williamson, “Comparative Economic Organization: The Analysis of Discrete Structural Alternatives," Administrative Science Quarterly 36 (1991), p.280.

${ }^{58}$ Wayne E. Baker, “Market Networks and Corporate Behavior.” American Journal of Sociology 96 
(1990), pp. 589-625.

${ }^{59}$ Powell characterizes the continuum view as quiescent and mechanical and argues that by "sticking to the twin pillars of markets and hierarchies, our attention is deflected from a diversity of organizational designs that are neither fish nor fowl, nor some mongrel hybrid, but a distinctly different form, " Walter Powell, “Neither Market Nor Hierarchy: Network Forms of Organization,” Research in Organization $\underline{\text { Behavior }} 12$ (1990), 295, 298, 299. Also see J. Carlos Jarillo, “On Strategic Networks,” Strategic Management Journal 9 (1988), pp. 31-41 and Hans B. Thorelli, “Networks: Between Markets and Hierarchies," Strategic Management Journal 7 (1986), pp. 37-51.

${ }^{60}$ OECD, Technology and the Economy: The Key Relationship, p.78 (emphasis in original).

${ }^{61}$ Noel M Tichy, Michael L. Tushman and Charles Fombrun. "Social Network Analysis for Organizations," Academy of Management Review (4/4) (1979), pp. 509.

${ }^{62}$ Walter W. Powell, “Neither Market Nor Hierarchy: Network Forms of Organization,” pp. 300-1. ${ }^{63}$ Ibid.

${ }^{64}$ J. Carlos Jarillo, “On Strategic Networks,” Raymond Miles and Charles C. Snow, “Organizations: New Concepts for New Norms," and Hans B. Thorelli, "Networks: Between Markets and Hierarchies." ${ }^{65}$ Wayne E. Baker, “Market Networks and Corporate Behavior.”

${ }^{66}$ Martin, Mitchell, Swaminathan, 1993 and Walter W. Powell, “Neither Market Nor Hierarchy: Network Forms of Organization.”.

${ }^{67}$ Nitin Nohria and Robert C. Eccles Networks and Organizations: Structure, Form and Action, p.7, also see Fombrun 1993 and Barry Wellman and S. D. Berkowitz. Social Structures: A Network Approach.

${ }^{68}$ Manuel Castells, The Rose of the Network Society, p.147. 
${ }^{69}$ Paul Hirst and Graham Thompson, “The Problem of Globalization: International Economic Relations, National Economic Management and the Formation of Trading Blocs."

${ }^{70}$ Peter Dicken, Global Shift, p.149.

${ }^{71}$ See Manuel Castells, “The Informational Economy and the New International Division of Labor.” W. Michael Blumenthal, “The World Economy and Technological Change." Foreign Affairs 66 (1988), pp. 529-550.; Thomas H. Lee and Proctor P. Reed (eds.), National Interests in an Age of Global Technology (Washington: National Academy Press, 1991); and Robert B. Reich, The Work of Nations. ${ }^{72}$ Eric J. Hobsbawm, The Age of Extremes, p. 135.

${ }^{73}$ Robert O. Keohane, “Sovereignty, Interdependence, and International Institutions,” in Linda B. Miller and Michael Joseph Smith (eds.), Ideas and Ideals: Essays on Politics in Honor of Stanley Hoffman (Boulder: Westview Press, 1993), pp. 91-107.

${ }^{74}$ David Held and Anthony McGrew, “Globalization and the Liberal Democratic State,” Government and Opposition 28 (3) (1993), p. 265.

${ }^{75}$ John Gerard Ruggie, "Territoriality and Beyond: Problematizing Modernity in International Relations," International Organization 47 (1) (1993), pp.139-174. J. Samuel Barkin and Bruce Cronin, "The State and the Nation: Changing Norms and the Rules of Sovereignty in International Relations." International Organization 48 (1) (1994), pp.107-130. External sovereignty includes the concept of "juristical statehood," that states are organizations recognized by established states as sovereign. Keohane, “Sovereignty, Interdependence, and International Institutions," p. 96.

${ }^{76}$ Hendrik Spruyt, The Sovereign State and its Competitors (Princeton: Princeton University Press, 1994). 
${ }^{77}$ Robert O. Keohane and Joseph S. Nye, Power and Interdependence (Glenview, Ill.:

Scott Foresman and Company, 1989), p. 248.

${ }^{78}$ Mark Zaekher, "The Decaying Pillars of the Westphalian Temple: Implications for International Order \& Governance,” in James N. Rosenau \& Ernst-Otto Czempiel (eds.), Governance Without Government: Order and Change in World Politics (Cambridge: Cambridge University Press, 1992), p. 60 (emphasis in original).

${ }^{79}$ Nicholas Negroponte, Being Digital, 1st ed. (New York: Knopf, 1995).

${ }^{80}$ S.K. Pandit, "Wired to the Rest of the World," Financial Times (January 10, 1995), p. 12.

${ }^{81}$ Susan Strange, The Retreat of the State: The Diffusion of Power in the World Economy (Cambridge: Cambridge University Press, 1996).

${ }^{82}$ Geoffrey L. Goodwin, “The Erosion of External Sovereignty?”, in Ghita Ionescu (ed.), Between Sovereignty and Integration (New York: John Wiley and Sons, 1974), p.101.

${ }^{83}$ Spruyt, The Sovereign State and its Competitors, p.35.

${ }^{84}$ James Anderson, "The Modernity of States," in James Anderson (ed.), The Rise of the Modern State (Atlantic Highlands, N.J.: Humanities Press International, Inc, 1986), p.117. Also see Hedley Bull, The Anarchical Society: A Study of Order in World Politics, James (1986) and Gianfranco Poggi, The State:

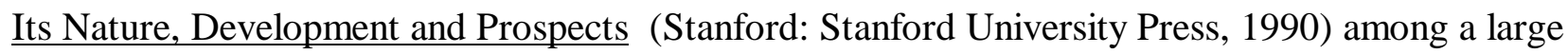
number of other authors discussing this subject.

${ }^{85}$ Ruggie, "Territoriality and Beyond: Problematizing Modernity in International Relations," p.151.

${ }^{86}$ Joseph Camilleri and Jim Falk, The End of Sovereignty? (Hants, England: Edward Elgar, 1992), p.238. Similarly, Krasner argues that the "central characteristic" of the sovereignty regime is exclusive 
control over a given territory, Stephen D. Krasner, "Westphalia and All That," in Judith Goldstein and Robert O. Keohane (eds.), Ideas and Foreign Policy (Ithaca: Cornell University Press, 1993), p.259. ${ }^{87}$ Ronald Deibert, “Harold Innis and the Empire of Speed” Review of International Studies. 25 (1999), p. 287.

${ }^{88}$ As Braudel notes, their development was far from spontaneous: “The national market was a form of coherence imposed by both political ambitions ....and by the capitalist tensions created by trade...a political space transformed by the state into a coherent and unified economic space...a large scale economy, territorialized so to speak, and sufficiently coherent for governments to be able to shape and maneuver it to some extent...", Braudel, Afterthoughts on Material Civilization and Capitalism, p. 99 and Fernand Braudel, The Perspective of the World Civilization and Capitalism: $15^{\text {th }}-18^{\text {th }}$ Century Vol. III (New York: Perennial Library, Harper and Row, 1986), p. 277, 294.

${ }^{89}$ Richard N. Cooper, Economic Policy in an Interdependent World (Cambridge: The MIT Press, 1986). ${ }^{90}$ UNCTAD 1994, p.118.

${ }^{91}$ UNCTAD 1994, p.119.

${ }^{92}$ Walter B. Wriston, The Twilight of Sovereignty (New York: Charles Scribners' and Sons, 1992).

${ }^{93}$ John M. Stopford and Susan Strange, Rival States, Rival Firms: Competition for World Market Shares. (Cambridge: Cambridge University Press, 1991), p.40 and Richard O’Brien, Global Financial Integration: The End of Geography (London: Pinter Publishers, 1992).

${ }^{94}$ Business Week, “Technobanking Takes Off”, pp. 52-53.

95 Joseph S. Nye, Bound to Lead: The Changing Nature of American Power (New York: Basic Books, 1990). 
${ }^{96}$ Ruggie, “Territoriality and Beyond: Problematizing Maodernity in International Relations,” 1993, p.

172. Also see Manuel Castells and Jeffrey Henderson. "Techno-economic Restructuring, Sociopolitical Processes and Spatial Transformation: A Global Perspective,” in Jeffrey Henderson and Manuel Castells (eds.), Global Restructuring and Territorial Development (Beverly Hills: Sage Publishers, 1987), pp.1-117.

${ }^{97}$ Peter Dombrowski and Richard Mansbach, "From Sovereign States to Sovereign Markets?” (Working Paper, Department of Political Science, Iowa StateUniversity, 1998), p. 4.

${ }^{98}$ Camilleri and Falk, The End of Sovereingty?, p.11. Similarly, Ruggie argues that the concept of sovereignty is no more than the "doctrinal counterpart of the application of single-point perspectival forms to the spatial organization of politics," Ruggie, "Territoriality and Beyond: Problematizing Modernity in International Relations," p.159

${ }^{99}$ Gianfranco Poggi, The State: Its Nature, Development and Prospects, and Friedrich Kratochwil, "Of Systems, Boundaries, and Territoriality: An Inquiry Into the Formation of the State System," World Politics XXXIX (1) (1986), pp. 27-52.

${ }^{100}$ Miles Kahler, International Institutions and the Political-Economy of Integration (Washington: The Brookings Institution, 1995), p. 1.

${ }^{101}$ Paul Kenendy, Preparing for the Twenty-first Century (New York: Random House, 1993) and Ruggie, "Territoriality and Beyond: Problematizing Modernity in International Relations." ${ }^{102}$ Martin Parker, “Post-modern Organizations or Postmodern Theory?” Organization Studies 13 (1) (1992), pp. 1-17.

${ }^{103}$ See Stephen J. Kobrin, “Neo-Medievalism and the Post-Modern World Economy.” Journal of 
International Affairs 51 (2) (Spring, 1998a) for an article length discussion of this theme. Parts of this section are taken from that article.

${ }^{104}$ W. Michael Bartlett, "The World Economy and Technological Change," Foreign Affairs 66 (1988), pp. 529-550.

${ }^{105}$ Edward Hallett Carr, The Twenty Years Crisis, 1919-1939. New York: Harper and Row Publishers, 1964, 1946. p. 229.

${ }^{106}$ Hedley Bull, The Anarchical Society: A Study in World Politics.

${ }^{107}$ John Gerard Ruggie, "Continuity and Transformation in World Politics: Toward a Neorealist Synthesis." World Politics, XXXV, n. 2, 1983, p. 274.

${ }^{108}$ Hendrik Spruyt, The Sovereign State and its Competitors (Princeton: Princeton University Press, 1994).

${ }^{109}$ Mark Schoofs and Michael Waldhotz, "New Regimen: AIDS-Drug Price War Breaks Out in Africa." The Wall Street Journal,_March 7, 2001,_sourced electronically.

${ }^{110}$ James Rosenau, Turbulence in World Politics (Princeton: Princeton University Press, 1990), p.247.

${ }^{111}$ John Gerard Ruggie, “Continuity and Transformation in the World Polity: Toward a Neorealist Syntheses," World Politics (1983), p.273.

${ }^{112}$ Camilleri and Falk, The End of Sovereignty?

${ }^{113}$ Hirst and Thompson, "The Problem of Globalization: International Economic Relations, National Economic Management and the Formation of Trading Blocs," p. 422.

${ }^{114}$ Ruggie notes at least three ways in which systems of rule have differed from the modern territorial state. First, they need not be territorial at all; second, they need not be territorially fixed; and third, they 
may not entail mutual exclusion, "Territoriality and Beyond: Problematizing Modernity in International Relations," p.49.

${ }^{115}$ (Camilleri and Falk, The End of Sovereignty?, p.52. 